\title{
DEVELOPMENT TEACHING BASIC SKILL'S VCD MEDIA TO IMPROVE TEACHING SKILLS IN SUBJECTS MICRO TEACHING
}

\author{
Satutik Rahayu*1, Nur Lestari², I Gde Mertha ${ }^{2}$ \\ ${ }^{1}$ Physics Education Study Program, University of Mataram \\ ${ }^{2}$ Biology Education Study Program, University of Mataram \\ * Email: satuti4977@yahoo.co.id
}

\begin{abstract}
This study aims to: 1) determine the quality of the results of VCDs that have been developed, 2) find out whether there is an increase in student teaching skills in micro-learning. This research is a development research using ADDIE (Analysis, Design, Development, Implementation and Evaluation) models. Validation of learning videos is done by learning media experts and user response questionnaires. Data analysis used descriptive analysis and N-Gain test. The results showed that the average score of the media expert validation was $86.7 \%$ which is in good and usable category, while the results of the user response questionnaire were $87.9 \%$ that is in good category and suitable for use. The $N$-Gain test found that there was an increase in the basic teaching skills of students after using the VCD which value was 0.7 .
\end{abstract}

Keywords: Media, VCD, Basic Teaching Skills, Micro Teaching

\section{INTRODUCTION}

Micro teaching is a compulsory subject that must be taken by Physics education students in the sixth semester. The micro teaching course contains the nature of micro teaching and eight basic teaching skills (Satutik et al. 2017). Singh \& Sharma (2004) state that micro-learning is a teaching practice procedure with a reduction in time and number of students for more specific teaching skills. This course is a course that discusses how to practice the eight basic skills of teaching in a teaching exercise in a small group. Eight basic skills teaching in question is 1 . Opening and closing of the lesson (set of induction and closures), 2. Skill to ask (questioning skill), 3. Skill to hold variation (variation skill), 4. Skill to provide reinforcement (reinforcement skill), 5. Skill to explain (explaining skill), 6. Skill to guide small group discussions, 7. Skill to manage classes, and 8. Skill to teach small groups and individuals. The basic teaching skills are the key to the success of prospective teachers in carrying out the teaching process (Rahayu \& Mertha, 2017).
Basic teaching skills can be trained in micro teaching lectures.

Micro teaching courses at the University of Mataram Physics education program are still using the old pattern by explaining the contents of the eight basic teaching skills to students through conventional learning without using learning media after students practice it. Based on the results of the analysis during the learning process without using media so far in addition to the value of teaching skills that are still low there are also several obstacles where there are still many students who are not appropriate in applying eight basic teaching skills, there are still many students who are still confused about how to apply reinforcement techniques. This is because students often forget the order in the procedure for implementing learning which includes preliminary activities, core activities and closing activities in the implementation of learning. Learning skills will be better if it is delivered using the help of audiovisual media. The use of audio-visual media can help students memorize the movements of 
the movements in the video so that students can easily follow the movements in how to teach correctly. Technological advances offer various facilities for humans to obtain information in a short time (Herayanti et al. 2015). One of the technological developments used for the learning process is in the form of media. The media has a significant contribution in teaching and learning activities (Hasan, 2016). The role of the media in the learning process is so that the information delivered is easily accepted by students. Audio-visual technology is a way of producing or delivering material using mechanical and electronic machines to present audio and visual messages. Based on the above problems, it is very important to develop VCD media basic teaching skills as micro teaching media to improve student teaching skills.

\section{RESEARCH METHOD}

This research is a research and development ( $\mathrm{R} \& \mathrm{D})$. The model that becomes a reference in the development of learning video media is the ADDIE model which consists of five steps, namely: (1) analysis (2) design (3) development (4) implementation and (5) evaluation (Tegeh \& Kirna, 2013). Broadly speaking, the four stages are as follows:

\section{Analyze}

At this stage is to define and define the learning conditions beginning with analyzing the objectives of the boundaries of the material developed by the device. The following in more detail the steps for developing learning media in the form of VCD chips that have been carried out are analyzing needs including: a) Analysis of the curriculum being used, b) Analysis of Syllabus, c) Material Analysis, d) Student analysis, e) Analysis media, f) Analysis of learning models and g) Design of CD media

2. Design

In the design of making media consists of:

a. Assessment of learning material Assessment of learning material is very important to determine which learning material will be used as the object of research. In this study the material to be developed is eight basic teaching skills

b. Media device

At this stage, researchers analyze media devices used for media development. The media device used for video making is the Sony Vegas Pro 13.0 program

c. Assessment of media usage

Media assessment is used to find out whether the media - the media used are suitable. Based on teaching experience, the researchers determined that audiovisual media is very suitable for learning basic teaching skills.

d. Make flow charts

Story boards and learning video scripts according to the content of the material that has been determined.

e. Collection of Design Objects Stages of collecting objects consisting of:

- Shooting

Image taking is done through three stages according to the syntax of lesson study activities, namely the plan, do and see activities.

- Collection of images

The collection of images is used to select and sort the images that will be combined into one display of coherent activities. 
- Collection / collection of text material to be delivered

- Making text

- Graphic creation

- Voice collection

- Video collection

f. Making Media Design

The purpose of the design stage is to make detailed specifications of the media to be made, including the cover of the chip box, the cover of the VCD chip, the design of the contents: opening, introduction, procedural contain learning which includes preliminary activities, core activities, closing activities, and closing media.

3. Development

The purpose of this stage is to develop a prototype of the contents of the learning
VCD. Stages of object assembly that have been made by combining animation, text, sound, and graphics into an alignment in appearance and sound are adjusted to the script using the help of hardware (hardware) a computer set with good graphics capabilities. The supporting software used is the Sony Vegas Pro 13.0 program. The steps for making VCD are shown in Figure 1.

4. Implementation

The stages of implementation are stages where the video basic teaching skills that have been developed and have been validated are implemented in micro teaching by involving students as target media users.

5. Evaluation

The evaluation stage is the stage of evaluating video users that has been implemented in the research subjects.

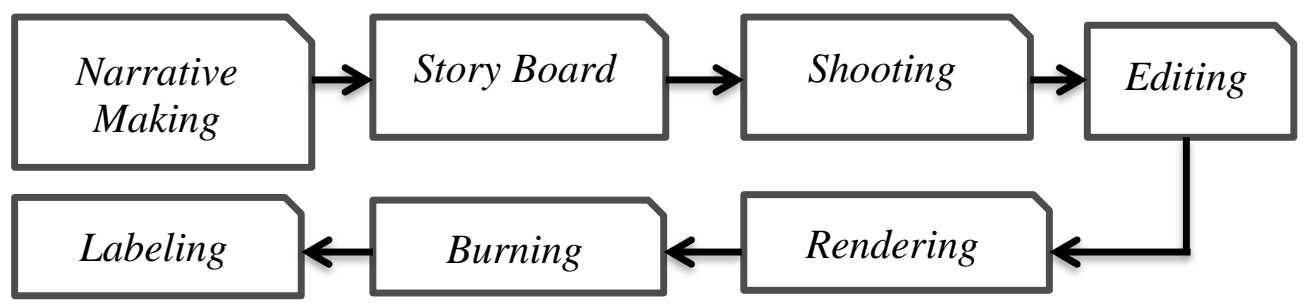

Picture 1. Making VCD Media's Flowchart

The Evaluation Tool uses a device validation sheet, a data collection tool in the form of a questionnaire, using the Rating Scale. Aspects of assessment of learning media and questionnaire sheets for student responses to VCD media. Analysis of VCD media

Value $=\frac{\sum \text { score }}{\text { Score } \max } \times 100 \%$

Analysis of improving teaching skills using Gain test (Hake, 1999). The Gain test equation is as follows:

$<G>_{\text {max }}=\frac{\left(\%<s_{f}>-\%<s_{i}>\right)}{\left(100-\%<s_{i}>\right)}$

Where $s_{f}=$ post-test value $s_{i}=$ pretest value
Table 1. Media VCD Feasibility

\begin{tabular}{lll}
\hline No & Value & Information \\
\hline A & $90 \%-100 \%$ & $\begin{array}{l}\text { Decent / Good is used } \\
\text { in the field without any } \\
\text { revisions.. }\end{array}$ \\
\hline B & $80 \%-89 \%$ & $\begin{array}{l}\text { Decent / Good is used } \\
\text { in the field with little } \\
\text { revision. }\end{array}$ \\
\hline C $\quad 70 \%-79 \%$ & $\begin{array}{l}\text { Less feasible / Less } \\
\text { Good to use with } \\
\text { revisions }\end{array}$ \\
\hline D & $<69 \%$ & $\begin{array}{l}\text { Not feasible / Not } \\
\text { good to use in the field }\end{array}$ \\
\hline
\end{tabular}

Table 2. Grade Value G

\begin{tabular}{lc}
\hline \multicolumn{1}{c}{ Value G } & Grade \\
\hline$(<\mathrm{G}>)>0.7$ & height \\
\hline $0.7>(<\mathbf{G}>)>0.3$ & medium \\
\hline$(<\mathrm{G}>)>0.3$ & low \\
\hline
\end{tabular}




\section{RESULTS AND DISCUSSION}

Video basic teaching skills that have been developed are then validated by media experts to obtain input and suggestions from media experts, which are then input and suggestions used for revision or improvement of VCD media so that VCD media is feasible to be used as learning media. The results of the validation by media experts obtained results as in table 3.
Table 3. Summary of Results of Validation of Media and Learning Experts

\begin{tabular}{clc}
\hline No & Aspect & Average value \\
\hline 1 & Format & $85.0 \%$ \\
2 & content & $87.5 \%$ \\
3 & language & $87.5 \%$ \\
& Average & $\mathbf{8 6 . 7 \%}$ \\
\hline
\end{tabular}

Based on the results above it can be concluded that on average $86.7 \%$ means that VCD media is feasible to use with a slight revision. The results of the validation of VCD media experts that have been developed are summarized in Table 4.

Table 4. Summary of VCD Media Validation Results

\begin{tabular}{lll}
\hline Description & \multicolumn{1}{c}{ Suggestion } & \multicolumn{1}{c}{ Revised results } \\
\hline $\begin{array}{l}\text { Opening } \\
\text { Section }\end{array}$ & $\begin{array}{l}\text { To add the logo of the University of } \\
\text { Mataram and FKIP }\end{array}$ & $\begin{array}{l}\text { add the logo of the University of } \\
\text { Mataram and FKIP }\end{array}$ \\
$\begin{array}{l}\text { Beginning } \\
\text { section }\end{array}$ & $\begin{array}{l}\text { In this section, add a review of the } \\
\text { material about the skills to open } \\
\text { learning for video skills to open } \\
\text { learning and basic teaching skills. }\end{array}$ & Add material descriptions \\
Duration & $\begin{array}{l}\text { Time for one video between } 15 \text { minutes } \\
\text { and } 20 \text { minutes }\end{array}$ & $\begin{array}{l}\text { Shorten the duration of time to 15 } \\
\text { minutes and } 17 \text { minutes }\end{array}$ \\
$\begin{array}{l}\text { Final } \\
\text { section }\end{array}$ & Thank you to funders & Showing thanks to funders \\
\hline
\end{tabular}

After the VCD media the basic teaching skills were revised and then used as a medium for micro teaching. Learning media is everything that can be used for learning materials, so it can stimulate the attention, interests, thoughts, and feelings of students in learning activities to achieve learning goals. Audiovisual media is one that becomes an intermediary or a means of delivering information that has sound, image, movement, animation, and light. Based on the results of the study of learning before using the media and after the use of VCD media the basic teaching skills were obtained as follows.

Table 5. Average Values Before and After VCD Media Usage

Basic Teaching Skills

\begin{tabular}{lcc}
\hline \multicolumn{1}{c}{ Assessment aspects } & $\begin{array}{c}\text { Average Value Before } \\
\text { Use of Media }\end{array}$ & $\begin{array}{c}\text { Average Value After } \\
\text { Media Usage }\end{array}$ \\
\hline Mastery of learning material & 76.47 & 87.75 \\
Learning Approaches and Strategies & 78.99 & 89.29 \\
Use of Resources / Media & 76.47 & 93.63 \\
& & \\
Learning that triggers Student & 65.59 & 90.00 \\
Engagement & 67.16 & 91.15 \\
Language Usage & 62.50 & 94.12 \\
Result Assessment & 70.22 & 92.28 \\
Closing Learning & & \\
\hline
\end{tabular}


Based on the results of the study it was obtained that the average value before using media (pre - test) was 71.06 while the average after using VCD media was the basic teaching skills (post-test) of 91.17. The result of the calculation of the $\mathrm{N}$ gain test is 0.7 which in the high category. It can be concluded that the teaching ability of students has a high increase after using VCD that have been developed. The use of media in learning has a positive effect on users. Learning media plays an important role in

learning

(Dewi et al . 2014). Learning media in the form of audiovisual media is very helpful for students in understanding the material, besides practically it contains visualizations of motion picture images and it can also be played back at home. The use of audiovisual media gives a positive heart to student users where they can easily understand the basic skills of teaching through visualization and movements that exist on the VCD media. This is reinforced by Arsyad (2011) who states that symbols visually facilitate the achievement of goals to understand and remember material. If the media program is designed and developed properly, then the function will be played by the media even without the existence of a teacher/teacher (Daru, 2011). Gunwan (2015) also stated that learning videos can be used to guide students to understand a material through visualization. Hamdanillah et al. (2017) showed the research's result that the advance organizer with video learning gave a significant influence on the physics learning outcomes of students of class XI MIA SMAN 2 Labuapi.

\section{CONCLUSION}

Based on the results of the study, it was found that the use VCD media of basic teaching skills can improve teaching skills in micro teaching courses. VCD media can help students learn by playing back the VCD. Media of VCD which contents the basic teaching skills that have been developed is expected to be used as micro teaching media by lecturers and students as well.

\section{THANK-YOU NOTE}

Our gratitude goes to Kemenristek Dikti for providing this research funding through the Institutional National Strategic Research (PSNI) grant in 2018 and the Unram University Research and Service Institution (LPPM) which has provided a forum for the development of lecturers' Research.

\section{REFERENCE}

Arsyad A. 2011. Media Pembelajaran. Jakarta: Grafindo Persada

Daru W. 2011. Pengembangan Media Pembelajaran Fisika Format Video Untuk Meningkatkan Kompetensi Siswa SMP. Proceding Seminar Nasional, Surakarta: Fakultas Keguruan dan Ilmu Pendidikan Universitas Sebelas Maret Surakarta

Gunawan. 2015. Model Pembelajaran Sains Berbais ICT. Mataram: FKIP Universitas Mataram Hamdanilah, N., Harjono, A., Susilawati. 2017. Pengaruh Model Pembelajaran Advance Organizer dengan Video Pembelajaran Terhadap Hasil Belajar Fisika Peserta Didik Kelas XI MIA SMAN 2 Labuapi. Jurnal Pendidikan Fisika dan Teknologi. 3(2), 119 - 127.

Herayanti, L., Fuaddunnazmi, M., Habibi. 2015. Pengembangan Media berbasis Moodle Pada Mata Kuliah Fisika Dasar. Jurnal Pendidikan Fisika dan Teknologi. 1(3), 205 - 209.

Purwono, J. Yutmini, S. Anitah, S. 2014. Penggunaan Media audio Visual Pada Mata pelajaran Ilmu Pengetahuan Alam di Sekolah 
Menengah Pertama Negeri 1 Pacitan. Jurnal Teknologi Pendidikan dan Pembelajaran. 2(2), 127 - 144.

Hasan, H. 2016. Penggunaan Media Audio Visual terhadap Ketuntasan Belajar IPS Materi perkembangan Teknologi Produksi, Komunikasi, dan Transportasi Pada siswa Kelas IV SD Negeri 20 Banda Aceh. Jurnal Pesona Dasar. 3(4), 22 - 33.

Hake, R.R. 1999. Analizing Change/Gain Scores. Dept. of Physics, Indiana University

Rahayu, S., Mertha, I.G. 2017. Micro Teaching. Lombok Barat: Arga Puji Press.

Rahayu, S., Mertha, I.G. 2017. Pengembangan Bahan Ajar Micro Teaching Untuk Melatih Kompetensi Pedagogik Calon Guru. Jurnal Pendidikan Fisika dan Teknologi. 3(2), 232-238

Tegeh, I.M., Kirna, I.M. Pengembangan Bahan Ajar Metode Penelitian Pendidikan dengan Model ADDIE. Jurnal IKA. 11(1), 12-26.

Singh, Y.K. \& Sharma, M.S.A 2004. Micro Teaching. New Delhi: A.P.H Publishing Corporation. 